\section{Spontaneous \\ hypoglycaemia due to a pleural fibroma: role of insulin like growth factors}

\author{
Ewan A Masson, Ian A MacFarlane, \\ David Graham, Patrick Foy
}

\begin{abstract}
A 64 year old woman with a long history of "drop attacks" and dizzy spells was found to have spontaneous hypoglycaemia. A slowly enlarging pleural mass had been present for at least five years. At thoracotomy the mass (weight $1.7 \mathrm{~kg}$ ) was excised and the hypoglycaemia ceased. Histologically the tumour was a pleuiral fibroma, with no features of malignancy. Endocrine tests before surgery showed a subnormal growth hormone response to spontaneous hypoglycaemia, a reduced concentration of serum insulin like growth factor I (IGF-I), and an inappropriately high concentration of serum insulin like growth factor II (IGF-II). After resection of the tumour the growth hormone response to insulin induced hypoglycaemia and the IGF-I and IGF-II concentrations were normal. These data suggest that the hypoglycaemia was due to production of IGF-II by the tumour, causing increased glucose utilisation and an impaired growth hormone counterregulatory response to hypoglycaemia.
\end{abstract}

Department of Medicine,

University of

Liverpool,

PO Box 147 ,

Liverpool L69 3BX

E A Masson

Walton Hospital,

Liverpool L9 1AE

I A MacFarlane

Regional Thoracic

Unit,

Fazakerley Hospital,

Liverpool L9 7AL

D Graham

Regional

Neurosciences Unit,

Walton Hospital,

Liverpool L9 1AF

P Foy

Reprint requests to:

Dr Masson

Accepted 16 July 1991 resection of the tumour (usually malignant), including mesenchy epithelial, and haematological lesions. most are found in the abdomen or retroperitoneum, around one third are in the thorax. Presentation with neuroglycopenic symptoms often precedes the recognition of the tumour. "Non-suppressible insulin like activity" is often present in the plasma with suppression of pancreatic insulin secretion, though candidate mechanisms are debated. We report a patient in whom serious hypoglycaemia was associated with abnormal serum concentrations of insulin like growth factor I and II (IGF-I, IGF-II), which returned to normal after resection of a benign pleural fibroma. The only reported case of spontaneous hypoglycaemia with similar pathological features was a recurrent lesion, also associated with abnormal IGF-II concentrations. ${ }^{3}$

\section{Case report}

A 64 year old woman presented to the neurosurgical unit with "drop attacks," headaches, and dizzy spells. Computer tomography suggested obstructive hydrocephalus due to Paget's disease of the skull, and a venticuloperitoneal shunt was inserted. On review two months later she was better but still had dizzy spells. One year later she returned complaining of frequent falls, episodes of confusion, and headaches. During an episode of confusion a low blood glucose concentration of 1.8 (normal $4-6$ ) $\mathrm{mmol} / \mathrm{l}$ was found. Her confusion resolved with intravenous dextrose. Frequent and often profound spontaneous hypoglycaemia continued. The hypoglycaemia was associated with low serum insulin concentrations (below $3 \mathrm{mU} / \mathrm{l}$ ), thereby excluding an insulinoma. The growth hormone response to hypoglycaemia was impaired and serum IGF-I concentrations were low (table). The response to a synacthen test was normal. High calorie supplementary feeds were required during the day and intravenous dextrose infusion was necessary overnight.

Four years previously an "encysted pleural effusion" had been found at another hospital. Pleural biopsy was not diagnostic and she had been lost to follow up. Review of previous radiographs revealed that the "pleural effusion," which had been present, apparently without symptoms, for at least five years, had increased considerably in size (fig 1). A pleural biopsy suggested a mesothelial tumour, and she underwent thoracotomy and resection of a $1.7 \mathrm{~kg}$ tumour measuring $19 \times 17 \times 8.5 \mathrm{~cm}$. Histological examination showed this to be a pleural fibroma (localised fibrous mesothelioma) with no definite features of malignancy.

She made good postoperative progress and

Growth hormone and insulin like growth factor I (IGF-I) concentrations during hypoglycaemia before and after

\begin{tabular}{llcc}
\hline & $\begin{array}{l}\text { Minimum blood } \\
\text { glucose (mmol/l) }\end{array}$ & $\begin{array}{l}\text { Maximum growth } \\
\text { hormone (mU/l) }\end{array}$ & $\begin{array}{c}\text { IGF-I } \\
(\text { nmol/l) }\end{array}$ \\
\hline Spontaneous hypoglycaemia (preoperative) & $0 \cdot 7$ & 6 & 3 \\
Insulin induced hypoglycaemia (postoperative) & $1 \cdot 4$ & 24 & 16 \\
\hline
\end{tabular}


(A) Radiograph from 1985 showing what was reported as an encysted pleural effusion. (B) Preoperative radiograph (1990) showing massive growth of the tumour.
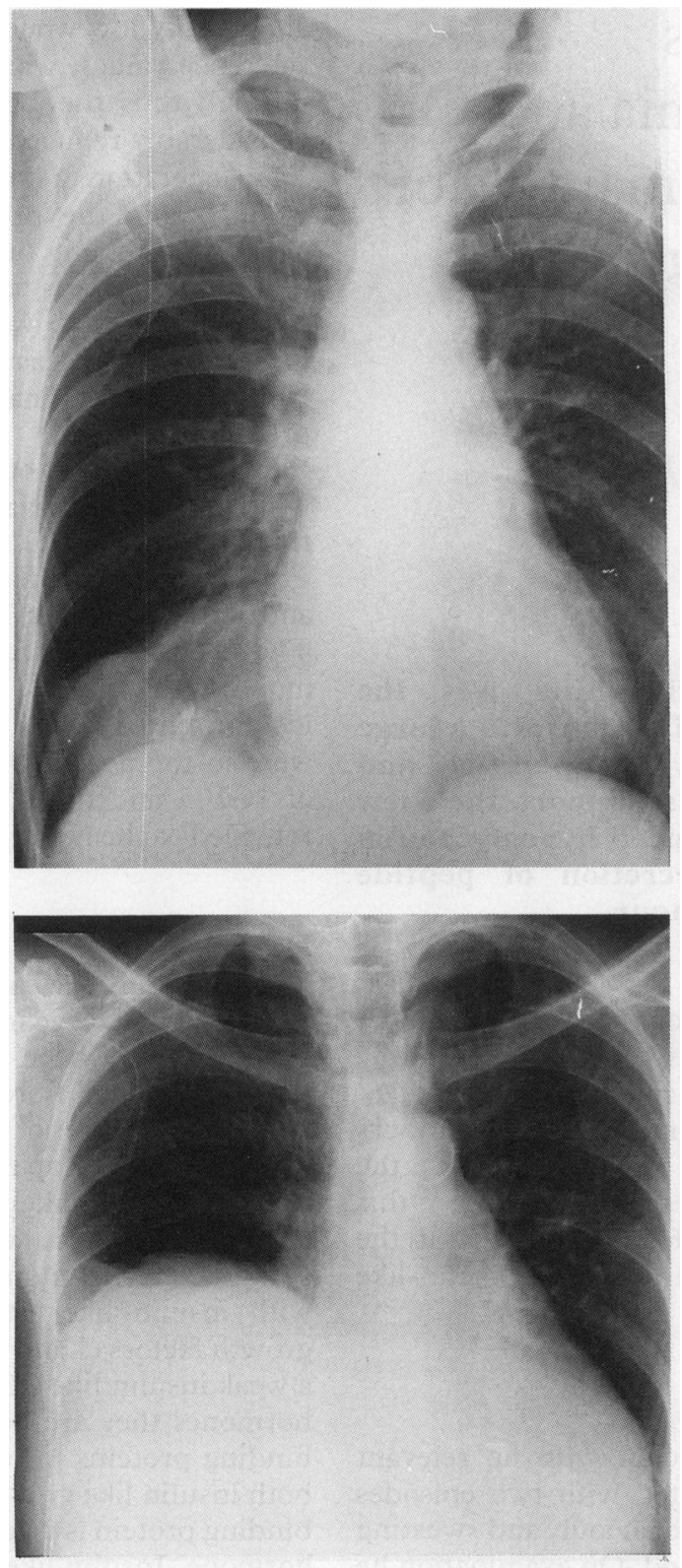

was discharged with no further hypoglycaemia. Endocrine testing three months later showed a fasting blood glucose concentration of $5.8 \mathrm{mmol} / \mathrm{l}$, a normal IGF-I concentration, and a normal serum growth hormone response to hypoglycaemia during an insulin stress test (table). The serum IGF-2 concentration fell from $1.64 \mathrm{U} / \mathrm{ml}$ (before operation) to $0.48 \mathrm{U} / \mathrm{ml}$, with a rise in the IGF-I:IGF-2 ratio from $0 \cdot 17$ to $1 \cdot 17$ (normal $>0 \cdot 2){ }^{4}$

\section{Discussion}

Spontaneous hypoglycaemia is initially investigated by measuring serum insulin concentrations at the time of hypoglycaemia, high concentrations indicating an insulinoma or abuse of sulphonylurea drugs. ${ }^{5}$ Insulin secretion by extrapancreatic lesions is extremely rare. ${ }^{2}$ In our patient serum insulin concentrations were low and were associated with a poor growth hormone response to hypoglycaemia, low serum IGF-I concentrations, and relatively high serum IGF-II concentrations. This suggested a non-islet cell tumour as the cause. $^{4}$
Insulin like activity (with suppression of pancreatic insulin secretion) has been found in the plasma in some cases of spontaneous hypoglycaemia associated with non-islet cell tumours. ${ }^{6}$ Insulin like growth factors are the principle source of non-suppressible insulin like activity in normal plasma, ${ }^{37}$ and recent work suggests that the ratio of IGF-I to IGFII may be important in paraneoplastic hypoglycaemia. ${ }^{4}$ Messenger RNA for IGF-II has been found in tissue from soft tissue tumours associated with hypoglycaemia, ${ }^{8}$ suggesting that IGF-II is secreted by the tumour. IGF-II can produce hypoglycaemia by several mechanisms. Interaction with insulin or IGF-I receptors enhances glucose uptake both as a paracrine effect within the tumour and as an endocrine effect on other tissues. Normally the high affinity of circulating insulin like growth factor binding proteins prevents any substantial interaction of this type, but IGF-II inhibits production of binding proteins. IGF-II mediated suppression of growth hormone secretion may also blunt the counterregulatory response to hypoglycaemia, as in this case. Removal of the tumour in our patient abolished fasting hypoglycaemia and restored the normal growth hormone response.

Benign pleural fibroma rarely causes spontaneous hypoglycaemia. One case of a recurrent pleural fibroma has been associated with hypoglycaemia and inappropriate IGF-II production, ${ }^{3}$ but most cases arise from tumours that are clearly malignant. ${ }^{1}$ Hypoglycaemia may be insidious and unrecognised. These patients tend to have symptoms associated with neuroglycopenia, which may be non-specific, especially in the elderly. In our patient hypoglycaemic symptoms had been present for some years before diagnosis and were initially attributed to obstructive hydrocephalus. The profound hypoglycaemia required nocturnal intravenous dextrose infusion preoperatively, so surgery was clearly indicated and resulted in immediate cure.

We would like to thank Dr J D Teale and Professor V Marks for the IGF-I/IGF-II ratio studies.

1 Gordon P, Hendricks CM, Khan CR, Megyesi K, Roth J. Hypoglycaemia associated with non-islet-cell tumour and insulin like growth factors. $N$ Engl J Med 1981;305: insulin

2 Daughaday WH. Hypoglycaemia in patients with non-islet cell tumours. Endocrinol Metab Clin N Am 1989;18: 91-101.

3 Ron D, Powers AC, Pandian MR, Godine JE, Axelrod L. Increased insulin-like growth factor II production and consequent suppression of growth hormone secretion: a dual mechanism for tumour-induced hypoglycaemia. $J$ Clin Endocrinol Metab 1989;68:701-6.

4 Teale JD, Marks V. Inappropriately elevated plasma insulin-like growth factor II in relation to suppressed
insulin-like growth factor I in the diagnosis of non-islet cell tumour hypoglycaemia. Clin Endocrinol 1990;33: 87-98.

5 Teale JD, Starkey BJ, Marks V, Hampton SM, Robinson J, Fisher RA, et al. The prevalence of factitious hypoglycaemia due to sulphonylurea abuse in the UK: a hypoglycaemia due to sulphonylurea abuse in the UK:

$6 \mathrm{Kahn} \mathrm{CR}$. The riddle of tumour hypoglycaemia revisited. Clin Endocrinol Metab 1980;9:335-60.

7 Guler HP, Zapf J, Froesch ER. Short term metabolic effects of recombinant human insulin-like growth factor $I$ in healthy adults. $N$ Engl $J$ Med 1987;317:137-40.

8 Lowe WL, Roberts CT, leRoith D, Rojeski MT, Merimee TJ, Fui ST, et al. Insulin-like growth factor-II in nonislet cell tumours associated with hypoglycaemia: increased levels of messenger ribonucleic acid. J Clin Endocrinol Metab 1989;69:1153-9. 